Article

\title{
Isotopic Results Reveal Possible Links between Diet and Social Status in Late Shang Dynasty (ca. 1250-1046 BC) Tombs at Xiaohucun, China
}

\author{
Ning Wang ${ }^{1, *}$, Lianmin Jia ${ }^{2}, \mathrm{Yi} \mathrm{Si}^{3}$ and Xin Jia ${ }^{4}$ (I) \\ 1 School of History, Culture and Tourism, Jiangsu Normal University, Xuzhou 221116, China \\ 2 Henan Provincial Institute of Cultural Heritage and Archaeology, Zhengzhou 450000, China; \\ jialianminhn@gmail.com \\ 3 School of History and Culture, Henan University, Kaifeng 475001, Henan, China; 10020113@vip.henu.edu.cn \\ 4 School of Geography, Nanjing Normal University, Nanjing 210023, China; jiaxin@njnu.edu.cn \\ * Correspondence: wanging3@gmail.com; Tel.: +86-0516-83536381
}

Received: 4 March 2020; Accepted: 23 April 2020; Published: 29 April 2020

\begin{abstract}
Here, we present evidence of possible links between diet and social status using carbon and nitrogen stable isotope ratios at the site of Xiaohucun in the Central Plains, China. This pilot study from a rescue excavation yielded humans $(n=12)$ identified to the late Shang Dynasty (ca. 1250-1046 BC), which was a warm climatic period. The population consumed a predominately $\mathrm{C}_{4} \operatorname{diet}$ (millets) and no difference was observed between the $\delta^{13} \mathrm{C}$ results of individuals $(\mathrm{n}=7)$ buried with $(-9.1 \pm 2.8 \%$ o $)$ and without $(\mathrm{n}=5)$ bronze vessels $(-8.2 \pm 0.7 \%$ o). However, individuals buried with bronze vessels $\left(10.3 \pm 1.6 \%\right.$ o) were found to have significantly higher $\delta^{15} \mathrm{~N}$ values (one-way ANOVA; $p=0.015$ ) compared to individuals buried without bronze vessels $(8.0 \pm 0.9 \%$ o), providing evidence that possible elite members consumed more animal protein (dog, pig, cow, sheep/goat). Isotopic results were also examined for social status in relation to the number of burial coffins that an individual had: double $(n=6)$, single $(n=3)$, or no coffin $(n=3)$. No difference was found in the $\delta^{13} C$ values, but variations were observed in the $\delta^{15} \mathrm{~N}$ values: double coffin $(10.2 \pm 1.7 \%$ o $)>$ single coffin $(8.8 \pm 1.8 \%$ o $)>$ no coffin $(8.0 \pm 1.3 \%$ o) , again possibly showing increased animal protein consumption linked to social status. Finally, isotopic results and status were studied by looking at the number of coffins and tomb size. Again, no correlation was observed for the $\delta^{13} \mathrm{C}$ results, but a strong linear correlation $\left(R^{2}=0.85\right)$ was observed for the $\delta^{15} \mathrm{~N}$ values of the individuals buried in two coffins vs. tomb size.
\end{abstract}

Keywords: human diet; hierarchy; bronze age; carbon and nitrogen stable isotope ratios

\section{Introduction}

Ancient China was a complex and highly socially stratified society [1-4]. Vast disparities existed between the nobility and the common people in areas such as rights, ownerships, diet, customs, behavior etc. These differences were chronicled in various historical works such as: Li Ji “礼记” which described how criminal law did not apply to senior officials and that etiquette did not apply to common people [5]. This social hierarchy of the living was also extended to the treatment of the dead, and the phrase: "Honor the dead as the living", recorded by Xun $\mathrm{Zi}$ “萌子", was and still is an important concept that is intertwined through the fabric of Chinese society [6,7]. Social status could also be maintained in the afterlife by the size and the scale of the tomb, and the quantity and quality of the grave goods interred with an individual [8-12].

Stable isotope ratio analysis has been successfully applied to examine dietary patterns in past populations from many societies across the globe [13-24]. Isotopic results of bone collagen primarily reflect the protein component of the diet averaged over the entire lifetime of an individual, including a large 
portion of collagen synthesized during later childhood and adolescence [25,26]. Briefly, stable isotope ratios are defined as the ratio of the heavier to the lighter isotope (e.g., ${ }^{13} \mathrm{C} /{ }^{12} \mathrm{C}$ or ${ }^{15} \mathrm{~N} /{ }^{14} \mathrm{~N}$ ) and are compared in terms of $\delta$ values in parts per 1000 or "per mil" (\%o) in relation to internationally defined standards for carbon (Vienna Pee Dee Belemnite, VPDB) and nitrogen (ambient inhalable reservoir, AIR) [27]. In Chinese archaeological research, $\delta^{13} \mathrm{C}$ measurements of human and animal collagen allow for an examination of the contribution of $C_{3}$ (rice, wheat, barley etc.) and $C_{4}$ foods (millets) to the diet. These studies have been vital for the reconstruction of a coarse time scale for the spread of different forms of agriculture in China [28-35] and for understanding animal husbandry practices [36-39]. The $\delta^{15} \mathrm{~N}$ results can be used as an estimation of the trophic level of a human or animal in a foodweb and are based on the observation of an increase of about $3 \%$ o $-5 \%$ o from the food to the consumer tissue [14,40,41]. Thus, levels of animal protein consumption can be examined with nitrogen isotope ratios. Modern human studies have found higher $\delta^{15} \mathrm{~N}$ values in omnivores compared to vegeterians and vegans [42,43]. However, an in-depth discussion on the intricacies of stable isotope ratios to reconstruct past diets is beyond the focus of this paper and the reader should consult the reviews of Katzenberg [44], Ambrose and Krigbaum [45], and Lee-Throp [46].

Increasingly, this technique is used to directly document dietary differences between social classes, e.g., elites vs. common people [47-52], and the reader is directed to consult Twiss [53] for a review of food and social diversity in archaeological and isotopic research. However, relatively little research has focused on the use of stable isotope ratios to directly determine dietary differences related to social status in China [54-58]. It is widely accepted that the Shang Dynasty (1600-1046 BC) is an early Chinese era based on abundant written records and the rich archaeological evidence [59-64]. Thus, this period is an extremely important phase in the development of the earliest Chinese civilization, and the formation of the ritual systems of power, class, and hierarchy [3]. Here, we present results of a small pilot study that examines dietary patterns related to social status for burials that date to the late Shang Dynasty (ca. 1250-1046 BC). Humans ( $n=12)$ from the site of Xiaohucun and animals $(n=11)$ from the nearby contemporaneous site of Guandimiao in Henan Province were available for study due to a rescue excavation. The results of this research will be the focus of this work [65].

\section{Background of Ritual Systems in Ancient China}

China has a long and vibrant tradition of organized rituals and hierarchy, and this is especially evident for dining practices as well as the type of food consumed [66-70]. A separate system of dining was very popular for the elite members of society. At dinner, individuals kneeled next to an Aiji “案基” (a kind of little table) and a selection of tableware was placed next to each person for holding cereals, meat, water, beverages, and liquor. The type, quality, and number of the dishes served were determined by the status and the age of the diners. Elders and people of high social status had the right to use more bronze vessels [69,71]. According to written accounts and archaeological data, the most important tableware in China were Ding “鼎” (an ancient vessel for cooking or holding meat) and Gui "笽" (an ancient vessel for holding grains), and a combination of both is the Chinese characters for banquet “飨宴”, which was a symbol associated with nobility [72] (Figure 1). The number of Ding and Gui that a person could use in life was consistent with their social status, and this was also reflected in the combination of these items that were buried with the dead (Table 1). In addition, the consumption of meat was a privilege of the nobility and elders of a family before the Qin Dynasty (Table 1). The work $\mathrm{Li} \mathrm{Ji}$ “礼记” recorded that “If there is not an important reason, the princes shouldn't kill cattle to eat, senior officials shouldn't kill sheep to eat, junior officers shouldn't kill dogs and pigs to eat, and the common people should not eat meat [5]. Thus, meat was a luxury dietary item that was generally reserved for elites and only for special occasions such as festivals or banquets. In addition, analysis of ceramics from the early Shang Dynasty site of Yanshi determined different structures and behaviors of dining between the palace elites and the individuals that made pottery [73]. Reinhart determined that the Yanshi elites engaged in large-scale exclusionary feasting in contrast to the simpler and home cooked meals of the potters. 


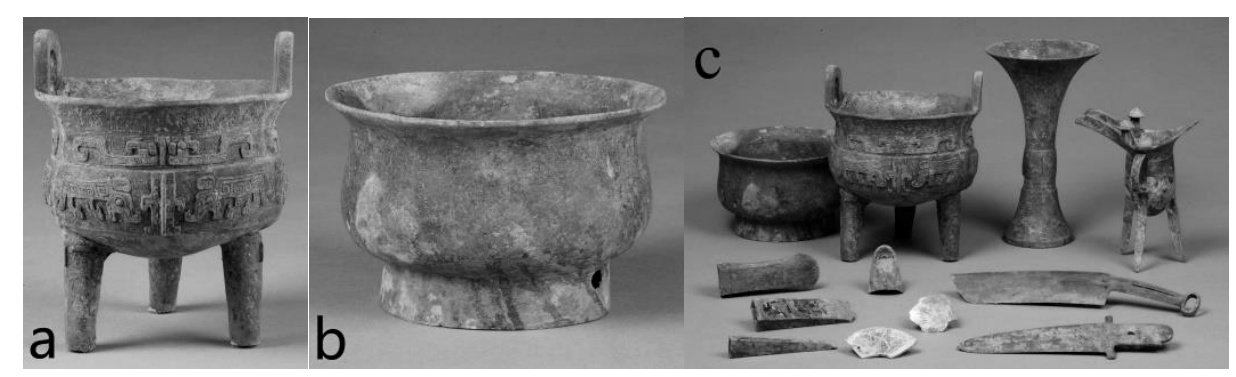

Figure 1. Bronze ritual vessels discovered in tomb M22 of Xiaohucun site $(\mathbf{a}=$ Ding, $\mathbf{b}=$ Gui, $\mathbf{c}=$ All bronze grave goods).

There were also strict rules for the maintenance of social status for the deceased in ancient China. Tomb size and burial depth (representing wealth and labor consumption) and the quantity and quality of the coffins used were some of the most important criteria reflecting social status (Table 1) [74,75]. The writings of Xun Zi “荀子” described that the number of coffins used for the Emperor was seven, for a prince was five, for senior nobility was three, and for junior nobility was two [6]. Furthermore, there were strict codes for the materials, size, thickness, as well as the internal and external decoration patterns of coffins, and this was related to hierarchy in Chinese society (Table 1). In addition, the type and quality of grave goods was an important manifestation of the status of the deceased. At least from the Zhou Dynasties, the combination of the number of bronze ritual vessels (Ding and Gui) played a very important role in the status of a tomb owner (Table 1) [3,72]. However, it is important to note that there is a chronological lag between these historical sources and the Shang period and that these works might be biased by the views of the writers. Thus, caution and some skepticism are advised in the use of these textual sources, and they should not be viewed as undisputed fact.

Table 1. Summary of selected differences based on social class in ancient China. This information is referenced from Liji “礼记” [5] except for “coffin number" which was referenced from Xun Zi “萌子” [6]. Note: Readers are advised that care must be taken with the accuracy of this information as it is compiled from historical sources which could be subject to the biases of the writers.

\begin{tabular}{cccccccccc}
\hline \multirow{2}{*}{ Status } & \multicolumn{2}{c}{ Diet } & \multicolumn{2}{c}{ Sacrifice } & \multicolumn{2}{c}{ Travel } & \multicolumn{2}{c}{ Burial } \\
\cline { 2 - 9 } & $\begin{array}{c}\text { Tableware and } \\
\text { Courses per Meal }\end{array}$ & Meat in Diet & $\begin{array}{c}\text { Bronze Vessels (Ding) } \\
\text { in Ritual Activities }\end{array}$ & $\begin{array}{c}\text { Carriage } \\
\text { Number }\end{array}$ & $\begin{array}{c}\text { Horse per } \\
\text { Carriage }\end{array}$ & $\begin{array}{c}\text { Coffin } \\
\text { Number }\end{array}$ & $\begin{array}{c}\text { Coffin } \\
\text { Material }\end{array}$ & $\begin{array}{c}\text { Ding + Gui } \\
\text { Combination }\end{array}$ \\
\hline Emperor & 26 & Yes & 7 & NA & 6 & 7 & N/A & $9 \& 8$ \\
\hline Prince & $12-16$ & Yes & Yes & 4 & 5 & 4 & 5 & Pine & $7 \& 6$ \\
\hline Senior Nobility & 8 & Yes & 1 & 3 & 2 & 2 & Miscellaneous & $3 \& 2$ \\
\hline Junior Nobility & 6 & Only older people & N/A & N/A & 1 & N/A & N/A & N/A \\
\hline Common People & $3-6$ & &
\end{tabular}

\section{Site of Xiaohucun, Henan Province, China}

The Xiaohucun site, dating to the late Shang (ca. 1250-1046 BC) and Western Zhou Dynasty (ca. 1046-771 BC), was the focus of a partial rescue excavation in 2006 by the Henan Provincial Institute of Cultural Relics and Archaeology. The site is situated to the northeast of Xiaohu Village in Xingyang City, which is about $20 \mathrm{~km}$ from Zhengzhou, the capital of Henan Province, China (Figure 2) [76]. This unique location is situated in the core of the Central Plains, which was the origin of many early civilizations of China, and also the political and economic center of the early Shang Dynasty. Based on archaeobotanical and isotopic research, the inhabitants of the Central Plains mainly relied on millet cultivation (rice and wheat were also present to some extent) and animal husbandry (pig, cattle, etc.) for subsistence $[1,3,34,66,77-80]$. 


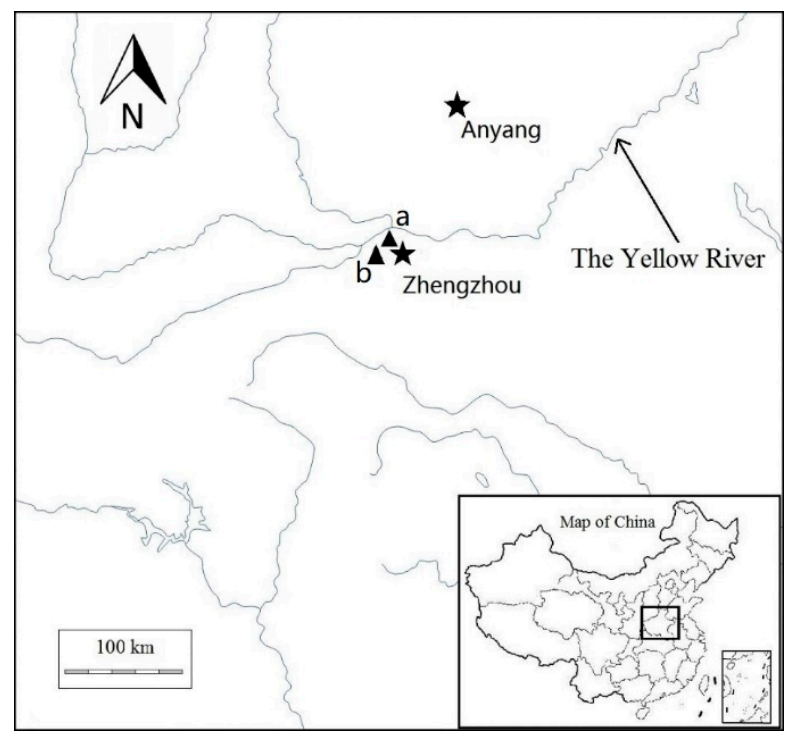

Figure 2. Map of China showing the location of the (a) Xiaohucun site and (b) Guandimiao site. Note: Zhengzhou is the capital of Henan Province.

A total of 58 tombs from the late Shang Dynasty (ca. 1250-1046 BC) were excavated from an area of $400 \times 200$ meters. All tombs are pits and rectangular in shape, and most had a platform consisting of: inner coffin, outer coffin, waste pit, sacrificial dogs, and various types of grave goods. Unfortunately, many tombs have been looted and destroyed and only 21 of them could be studied in any detail. According to the preliminary report from this site, all the 21 tombs can be divided into three styles, equivalent to the phases of the Yin Ruins II, III, and IV [81]. No radiocarbon dates are available from the site, but examination of the tomb style, grave goods, and the writing on the bronze vessels suggest that the cemetery was a family plot that belonged to the She "舌" family from the late Shang Dynasty. Many of the individuals were from the junior nobility class, but a number of common people were also interred here.

\section{Materials and Methods}

For the 21 tombs at Xiaohucun, bone samples consisting of long bone fragments were obtained from 12 late Shang Dynasty individuals for stable isotope ratio analysis. Osteological analysis, including sex determination and age estimation, was carried out according to standard methods [82]. Unfortunately, due to poor preservation and looting many of the skeletons were destroyed or incomplete and only 5 out of 12 individuals could be positively identified to gender and 9 out of 12 aged (Table 2). In addition, since Xiaohucun was a cemetery site, faunal samples were not available for study. However, we were able to obtain animal bones $(\mathrm{n}=11)$ from the nearby $(15 \mathrm{~km})$ and contemporaneous site of Guandimiao (ca. 1250-771 BC) which serves as a baseline estimation for the human diets (Table 3).

Collagen was extracted at the Key Laboratory of Vertebrate Evolution and Human Origins of the Chinese Academy of Sciences, Institute of Vertebrate Paleontology and Paleoanthropology in Beijing, China, using the protocol outlined by Richards and Hedges [83]. The extracted collagen was well preserved and the majority of samples had collagen yields of over 1\% and C: $\mathrm{N}$ between 3.0-3.2 (11/11 animals; $12 / 12$ humans), which is indicative of collagen suitable for isotopic analysis [84]. The samples were measured with an Isoprime 100 IRMS coupled with Elementar Vario. Standard material for testing the carbon and nitrogen content was sulfonamides. For every 10 samples, we interpolated one IEAE-CH-6, IEAE-N-2, and IEAE-600 to make data corrections. The measurement precision for $\delta^{13} \mathrm{C}$ and $\delta^{15} \mathrm{~N}$ results is $\pm 0.2 \%$ o. SPSS 20.0 and Origin 8.0 were used for statistical analysis. 
Table 2. Isotopic results and sample information for all humans from the Xiaohucun site, Henan Province, China.

\begin{tabular}{|c|c|c|c|c|c|c|c|c|c|c|c|c|c|c|c|}
\hline Lab ID & Location & Sex & Age & $\begin{array}{c}\text { Open Size } \\
\left(\mathrm{m}^{2}\right)\end{array}$ & $\begin{array}{l}\text { Depth } \\
\text { (m) }\end{array}$ & $\begin{array}{l}\text { Coffin } \\
\text { Type }\end{array}$ & $\begin{array}{c}\text { \# Grave } \\
\text { Goods }\end{array}$ & $\begin{array}{l}\text { Bronze } \\
\text { Vessels }\end{array}$ & $\begin{array}{c}\text { \# Bronze } \\
\text { Vessels }\end{array}$ & $\begin{array}{l}\text { \# Jade \& other } \\
\text { Objects }\end{array}$ & $\begin{array}{l}\delta^{13} \mathrm{C} \\
(\%)\end{array}$ & $\begin{array}{l}\delta^{15} \mathrm{~N} \\
(\% \mathrm{o})\end{array}$ & $\% \mathrm{C}$ & $\% \mathrm{~N}$ & C:N \\
\hline 1 & M8 & Male & $45-50$ & 7.35 & 4.30 & double & 6 & yes & 6 & - & -8.8 & 12.8 & 29.9 & 11.5 & 3.0 \\
\hline 2 & M24 & Male & $55 \pm$ & 5.52 & 1.80 & double & 8 & yes & 7 & 1 & -8.1 & 10.7 & 38.6 & 14.0 & 3.2 \\
\hline 3 & M27 & $?$ & $55 \pm$ & 5.61 & 2.60 & double & 8 & yes & 3 & 5 & -7.8 & 10.3 & 41.0 & 14.9 & 3.2 \\
\hline 4 & M30 & $?$ & $?$ & 4.57 & 2.00 & double & 7 & yes & 6 & 1 & -15.2 & 7.6 & 42.1 & 15.3 & 3.2 \\
\hline 5 & M39 & $?$ & $40-45$ & 3.92 & 1.00 & none & - & no & - & - & -8.6 & 6.7 & 40.2 & 14.9 & 3.1 \\
\hline 6 & M46 & $?$ & $35 \pm$ & 2.60 & 0.90 & single & - & no & - & - & -8.8 & 7.5 & 39.7 & 14.4 & 3.2 \\
\hline 7 & M47 & $?$ & $25-30$ & 1.92 & 1.60 & single & - & no & - & - & -7.5 & 8.2 & 38.4 & 14.1 & 3.2 \\
\hline 8 & M52 & $?$ & ? & 6.80 & 3.58 & double & 11 & yes & 5 & $\begin{array}{l}4 \text { (1 cowrie shell \& } \\
1 \text { wooden object) }\end{array}$ & -6.4 & 10.9 & 41.4 & 15.2 & 3.2 \\
\hline 9 & M89 & $?$ & $50-55$ & 2.30 & 0.70 & none & 1 & no & - & 1 & -7.4 & 8.2 & 41.2 & 15.2 & 3.2 \\
\hline 10 & M90 & Male & $40-45$ & 3.95 & 0.66 & single & 4 & yes & 2 & 1 (1 cowrie shell) & -9.3 & 10.8 & 39.6 & 14.7 & 3.2 \\
\hline 11 & M105 & Male & $?$ & 4.91 & 2.25 & double & 5 & yes & 4 & 1 & -8.0 & 9.2 & 40.0 & 14.8 & 3.1 \\
\hline 12 & M116 & Female & $45 \pm$ & 1.54 & 1.40 & none & 1 & no & - & (1 cowrie shell) & -8.5 & 9.2 & 37.5 & 13.5 & 3.2 \\
\hline
\end{tabular}

Table 3. Isotopic results and sample information for all fauna from the Guandimiao site, Henan Province, China.

\begin{tabular}{cccccccc}
\hline Lab ID & Location & Species & $\delta^{\mathbf{1 3}} \mathbf{C}(\mathbf{\% o})$ & $\delta^{\mathbf{1 5}} \mathbf{N}(\mathbf{\% o})$ & $\mathbf{\%} \mathbf{C}$ & $\mathbf{\% N}$ & $\mathbf{C : N}$ \\
\hline a 1 & H28 & Pig (Sus scrofa domestica) & -8.2 & 7.8 & 35.1 & 13.0 & 3.2 \\
\hline a 2 & H26 & Pig (Sus scrofa domestica) & -9.9 & 8.6 & 31.6 & 12.0 & 3.1 \\
\hline a 3 & H26 & Deer (Cervus nippon) & -20.5 & 4.9 & 36.2 & 13.0 & 3.2 \\
\hline a 4 & H741 & Pig (Sus scrofa domestica) & -6.7 & 6.6 & 41.8 & 15.0 & 3.2 \\
\hline a 5 & H932 & Pig (Sus scrofa domestica) & -9.3 & 7.6 & 41.0 & 14.8 & 3.2 \\
\hline a 6 & H932 & Dog (Canis lupus familiaris) & -7.6 & 8.6 & 37.3 & 13.7 & 3.2 \\
\hline a 7 & H1309 & Cattle (Bos primigenius & -9.0 & 5.7 & 41.9 & 15.2 & 3.2 \\
\hline a 8 & H1250 & Pig (Sus scrofa domestica) & -11.6 & 8.8 & 22.2 & 9.0 & 2.9 \\
\hline a 9 & H1251 & Deer (Cervus nippon) & -15.0 & 7.6 & 40.0 & 14.3 & 3.3 \\
\hline a 10 & J20 & Sheep/Goat (Caprinae) & -10.7 & 7.5 & 39.8 & 14.3 & 3.2 \\
\hline a 11 & G7 & Dog (Canis lupus familiaris) & -7.5 & 7.6 & 37.4 & 13.8 & 3.2 \\
\hline
\end{tabular}

\section{Results}

Sample information and the $\delta^{13} \mathrm{C}$ and $\delta^{15} \mathrm{~N}$ values for humans and animals are presented in Tables 2 and 3. Given the work at the Xiaohucun site was a rescue excavation, and many tombs were looted, we fully acknowledge that the number of humans available for study was relatively small, but this collection serves as a pilot study and the first opportunity to gain a glimpse into possible isotopic dietary differences related to status during the late Shang Dynasty (ca. 1250-1046 BC) in the Central Plains of China.

\subsection{Faunal Isotope Results}

In Figure 3 the isotopic results of the humans and animals are presented. The $\delta^{13} \mathrm{C}$ values for pigs $(n=5)$, dogs $(n=2)$, cow $(n=1)$, sheep/goat $(n=1)$ range from $-6.7 \%$ o to $-11.6 \%$, which indicates that all of these animals had a diet predominately, if not exclusively, based on $\mathrm{C}_{4}$ dietary protein sources. Past archaeological and isotopic research has revealed that millet agriculture was important to the residents of the Central Plains $[1,28,77,78,85]$, and that the livestock were mostly consuming millet or its byproducts during the Shang Dynasty [39]. In contrast to the domestic animals, the two deer had $\delta^{13} \mathrm{C}$ values that indicated either a mixed $C_{3} / C_{4}(-15.0 \%$ o $)$ or exclusive $C_{3}(-20.5 \%$ oo diet. The finding of a deer with the mixed diet is interesting as this could suggest that this animal lived near 
the settlement and grazed on the millet fields or that it was possibly kept as pet. Similar results for deer were found at the Xia Dynasty (2070-1600 BC) site of Xinzhai, also in Henan Provence, and these ${ }^{13} \mathrm{C}$-enriched deer were thought to have been possibly raised for the purposes of hunting by the elites of the society [86]. The dog $\left(8.1 \%\right.$ o), pig $\left(7.9 \pm 0.9 \%\right.$ o), and sheep/goat $(7.5 \%$ o $)$ all had similar $\delta^{15} \mathrm{~N}$ values, suggesting feeding at a similar trophic level, whereas the deer $(6.3 \%$ o) and cow $(5.7 \%$ o) were lower. However, this site was closed to the Yellow river, so we could not eliminate the possibility of ingesting freshwater or marine fish resources by human.

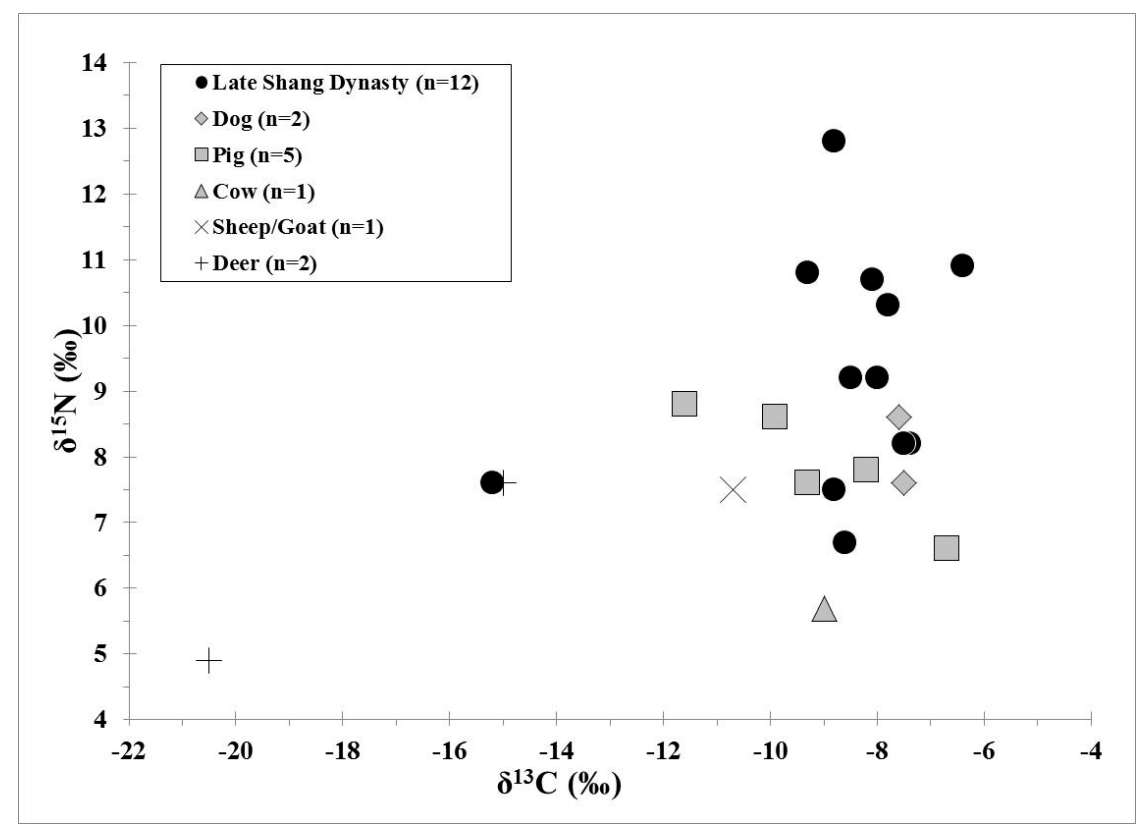

Figure 3. $\delta^{13} \mathrm{C}$ and $\delta^{15} \mathrm{~N}$ results for humans from the Xiaohucun site and animals from the Guandimiao site Henan Province, China.

\subsection{Human Isotope Results}

The human $\delta^{13} \mathrm{C}$ results range from $-15.2 \%$ o to $-6.4 \%$ ond show that most individuals had a predominately $\mathrm{C}_{4}$ diet based on millet (Figure 3). The exception was individual M30 (-15.2\%o) who had a mixed $C_{3} / C_{4}$ diet that was likely a combination of rice and/or wheat and millet [79,87]. The human $\delta^{15} \mathrm{~N}$ results range from $6.7 \%$ o to $12.8 \%$, indicating there was likely significant individual variation in the consumption of protein at the site. A comparison of the human and faunal isotopes values indicate that pigs, dogs, cattle, and sheep/goats were all likely dietary protein sources, while deer played a minor role (Figure 3). Thus, the diet of the individuals was predominately millet based with some possible inputs of rice and/or wheat, but there were large differences in $\delta^{15} \mathrm{~N}$ values that we ascribe to variations in animal protein consumption, as discussed in the next section.

\section{Discussion}

\subsection{Burials and the Classification of Social Status during the Late Shang Dynasty}

In order to determine a possible correlation between social status and dietary differences at the Xiaohucun site, it is important to understand how social status may have influenced the tomb type and value. In ancient China, tombs and burials can be graded and valued based on the human labor costs and materials used for construction, the size and shape of the structure, as well as the number and type of graves goods reflecting symbols of power and wealth interred with individuals [55,71]. Since the shapes of all the late Shang Dynasty burials at Xiaohucun were rectangular, the preliminary grading scale of the 12 tombs was classified by number of coffins, tomb depth, and size, and by the presence of 
bronze funerary objects and this information is listed in Table 1 and plotted in Figure 4 . Tomb sizes ranged from $1.54 \mathrm{~m}^{2}$ to $7.35 \mathrm{~m}^{2}\left(4.25 \pm 1.9 \mathrm{~m}^{2}, \mathrm{n}=12\right)$, the burial depth was between $0.66 \mathrm{~m}$ to $4.3 \mathrm{~m}$ $(1.93 \pm 1.1 \mathrm{~m}, \mathrm{n}=12)$, which could suggest that the cemetery was under a type of burial management based on social hierarchy. More importantly, the burial depth and tomb size were found to have a linear correlation $\left(\mathrm{R}^{2}=0.67, p=0.001\right)$ with clear differences between the number of coffins used and whether a burial contained bronze vessels.

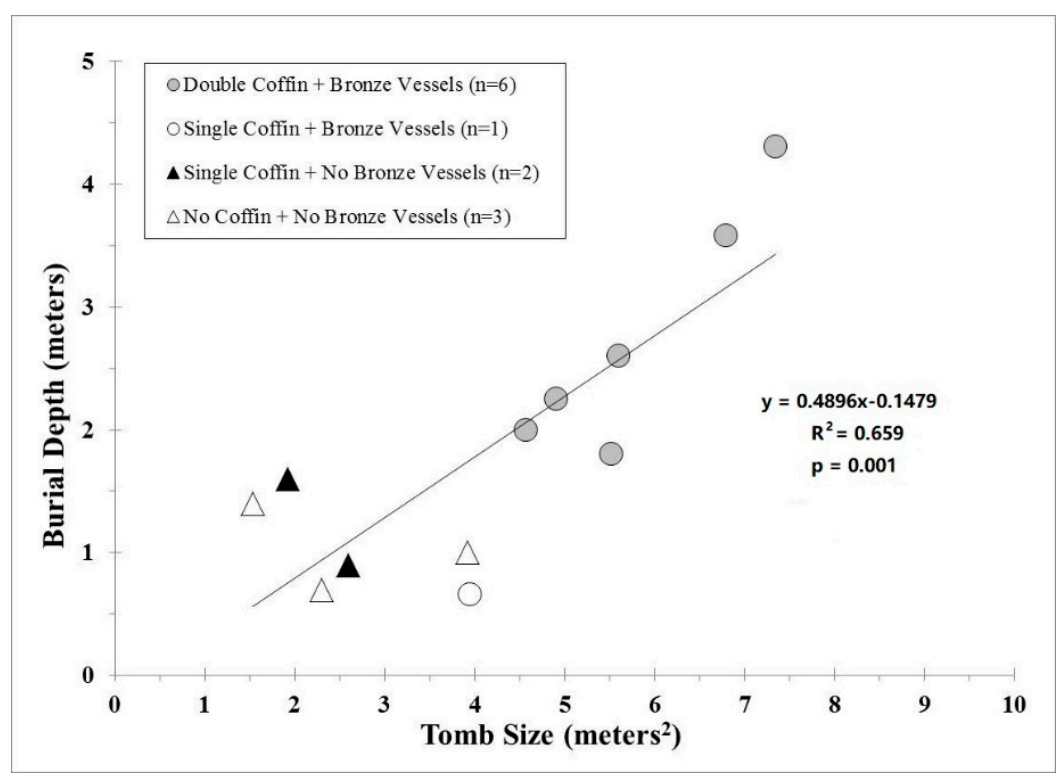

Figure 4. Plot of burial depth $(\mathrm{m})$ vs. tomb size $\left(\mathrm{m}^{2}\right)$ for individuals buried in different coffin types with and without bronze funerary vessels at the Xiaohucun site, Henan Province, China.

In addition, past studies developed a specific classification system for Shang Dynasty tombs [3,71], where they can be divided into three different categories $(\mathrm{A}, \mathrm{B}, \mathrm{C})$ with seven subdivisions $(\mathrm{Aa}, \mathrm{Ab}, \mathrm{Ac}$, $\mathrm{Ba}, \mathrm{Bb}, \mathrm{Bc}, \mathrm{C})$ (Table 4). Using this system, seven of the tombs (M8, M52, M27, M24, M105, M30, M90) at Xiaohucun are assigned to type $\mathrm{Bb}$. Thus, the owners of these seven tombs are presumed to be junior nobility: six had double coffins and all seven were buried with bronze funerary vessels. Four other tombs (M47, M46, M116, M89) were matched to the Bc category, an indication that the occupants were common people (Table 4). A single tomb (M39) gave somewhat conflicting results. The tomb size was large $\left(3.92 \mathrm{~m}^{2}\right)$ indicating the owner could have been a noble, but the individual was found to be buried without coffins or bronze funerary objects which is an indication this individual was of the lower class (Table 4). It is important to recognize that these classifications are based on information from the royal Shang capital at Anyang and may not be directly applicable at Xiaohucun. However, their use here provides an important starting point from which to explore the relationship between dietary differences and social status during the late Shang Dynasty.

\subsection{Diet and Social Status}

No difference is observed between the $\delta^{13} \mathrm{C}$ results of the perceived elites $(\mathrm{n}=7)$ buried with bronze vessels $(-9.1 \pm 2.8 \%$ o $)$ and the individuals $(n=5)$ buried without bronze vessels $(-8.2 \pm 0.7 \%$ o , and this indicates that all classes of the population relied heavily on a millet based diet (Figure 5a). However, individuals buried with bronze vessels $(10.3 \pm 1.6 \%$ o) were found to have significantly higher $\delta^{15} \mathrm{~N}$ values (one-way ANOVA; $p=0.015$ ) compared to individuals buried without bronze vessels $(8.0 \pm 0.9 \%$ o. This finding suggests that the elite during the late Shang Dynasty were consuming a diet with possibly more animal protein or fish than the commoners. Subtle similar patterns have also been noted at the sites of Xipo (ca. 4000-3300 BC) and Qianzhangda (ca. 1000 BC) [54,56]. In particular, 
at Qianzhangda, a tomb owner associated with a larger grave was found to have a higher $\delta^{15} \mathrm{~N}$ result compared to the other tomb owners with smaller sized burials, and tomb owners were also found to have higher $\delta^{15} \mathrm{~N}$ results than sacrificed individuals. Zhang et al. [56] concluded that these elevated nitrogen results of the elites with larger tombs were related to increased meat consumption. However, the results presented here are the first to suggest a possible direct isotopic link between diet and social status at a middle Shang Dynasty site from the Central Plains of China.

Table 4. Classification of social status for burials from the Shang and Zhou Dynasties. Note: Information is referenced from IA CASS [3].

\begin{tabular}{|c|c|c|c|c|c|c|c|}
\hline Type & Sub-Type & Tomb Passage & Size $\left(\mathrm{m}^{2}\right)$ & Inner \& Outer Coffins & Grave Goods & Human Sacrifice & Owner Status \\
\hline \multirow[b]{2}{*}{ A } & $\mathrm{a}$ & 4 & $>100$ & always & abundant & always & Emperor \\
\hline & $\mathrm{b}$ & 2 & $>20$ & always & abundant & always & Prince \\
\hline \multirow[b]{2}{*}{ B } & $\mathrm{a}$ & 0 & $>10$ & always & abundant & mostly & Prince or senior nobility \\
\hline & $\mathrm{b}$ & 0 & $3-10$ & mostly & ordinary & rarely & Junior nobility \\
\hline $\mathrm{C}$ & $\mathrm{a}$ & 0 & N/A & absence & absence & absence & Unprivileged people \\
\hline
\end{tabular}
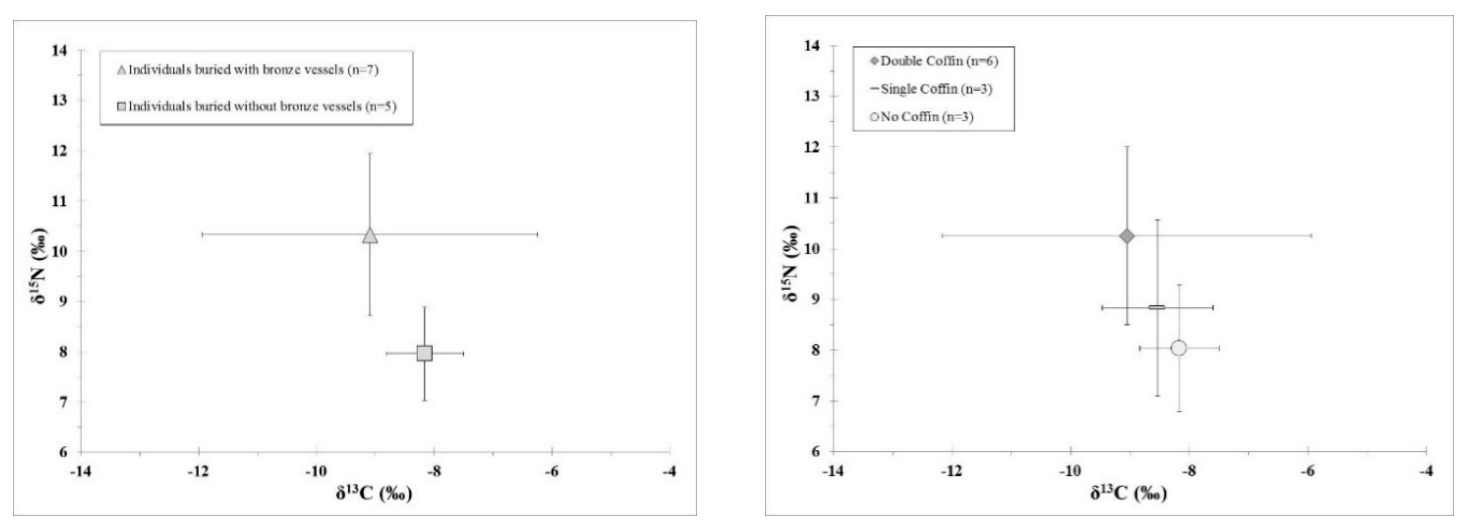

Figure 5. (a) $\delta^{13} \mathrm{C}$ and $\delta^{15} \mathrm{~N}$ results showing the differences between individuals buried with and without bronze vessels at the Xiaohucun site, Henan Province, China. The $\delta^{15} \mathrm{~N}$ results are statistically significant (one-way ANOVA; $p=0.015$ ); (b) $\delta^{13} \mathrm{C}$ and $\delta^{15} \mathrm{~N}$ results for individuals buried in a double, single, or without a coffin at the Xiaohucun site, Henan Province, China. The $\delta^{15} \mathrm{~N}$ results were not found to be statistically significant using one-way ANOVA tests (double vs. single, $p=0.288$; double vs. none, $p=0.095)$.

In addition, the isotopic values of the tombs were examined by coffin type: double coffin, single coffin, and no coffin (Figure $5 b)$. No differences in $\delta^{13} \mathrm{C}$ were observed for the double $(-9.1 \pm 3.1 \%$ o), single $(-8.5 \pm 0.9 \%$ o $)$, and no coffin $(-8.2 \pm 0.7 \%$ o $)$ burials. Yet again, there were differences in the $\delta^{15} \mathrm{~N}$ values: double $(10.2 \pm 1.7 \%$ o $)>$ single $(8.8 \pm 1.8 \%$ o $)>$ no coffin $(8.0 \pm 1.3 \%$ o suggesting that possible differences in animal protein consumption were present during the lifetime of these individuals. However, while these results are interesting, they must be viewed with the utmost caution as they were not found to be statistically significant using one-way ANOVA tests (double vs. single coffins, $p=0.288$; double vs. no coffins, $p=0.095$ ).

We further examined the isotopic results of the burials in relation to the number of coffins and tomb sizes since a larger size might equate to higher social status based on the increased labor costs of construction. This permitted an investigation of possible dietary differences within the same social class; specifically did individuals with larger tombs have diets different from individuals with smaller tombs? As with the previous measures of status, the $\delta^{13} \mathrm{C}$ values show little correlation with the size of the tombs, and the entire population, regardless of status, was focused on the consumption of millet (Figure 6a). The $\delta^{15} \mathrm{~N}$ results of the individuals with a single or no coffin burial show little 
correlation with tomb size (Figure $6 b$ ). In contrast, a significant positive linear correlation $\left(R^{2}=0.84\right)$ is observed for the $\delta^{15} \mathrm{~N}$ values between the individuals buried in two coffins and the tomb size. This is possible evidence that owners that were wealthy/powerful enough to build bigger tombs had diets that contained increasing amount of animal products, and the largest tomb (M8) had an occupant that consumed the most animal protein (Figure $6 \mathrm{~b}$ ). While these findings are intriguing and agree with the historical accounts described in Zhou Li “周礼” (Rites of the Zhou Dynasty by Zhou Gong “周公”, ca. 1100 BC [88]) and Chunqiu Gongyang Zhuan “春秋公羊传” (Gongyang's Commentary on Spring and Autumn Annals by Gongyang Gao “公羊高”, ca. 507 BC [89]) extreme caution is warranted as the sample size is unfortunately small.

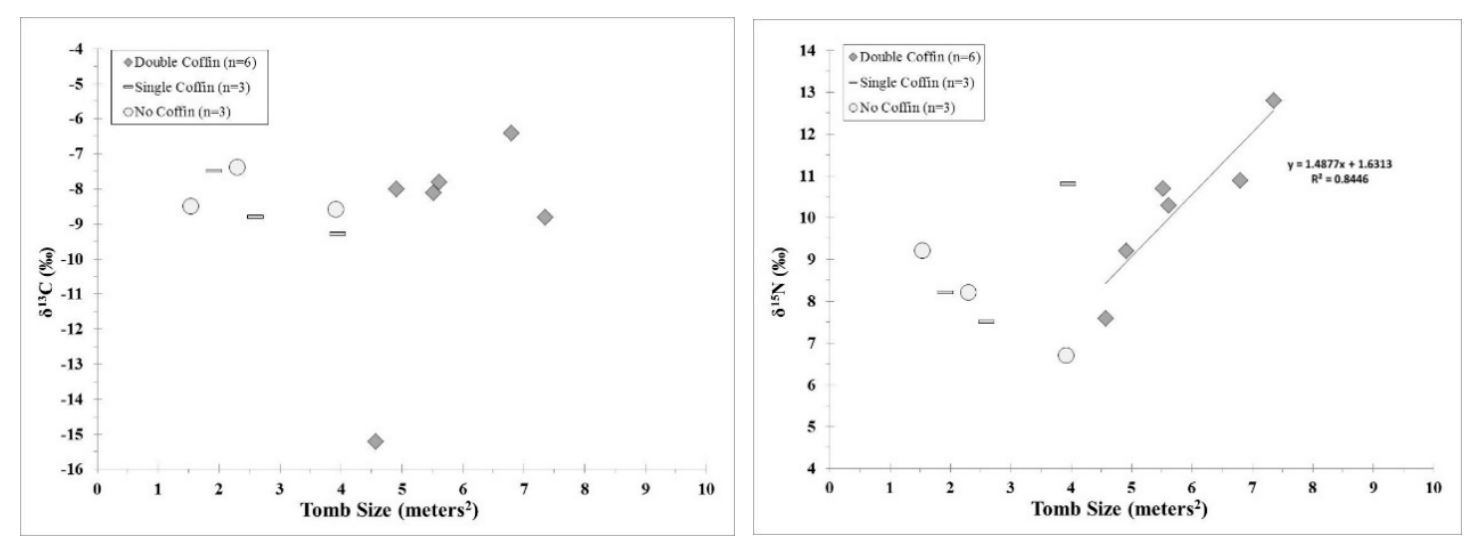

Figure 6. (a) $\delta^{13} \mathrm{C}$ results vs. tomb size $\left(\mathrm{m}^{2}\right)$ for individuals buried in a double, single, or without a coffin at the Xiaohucun site, Henan Province, China; (b) $\delta^{15} \mathrm{~N}$ results vs. tomb size $\left(\mathrm{m}^{2}\right)$ for individuals buried in a double, single, or without a coffin at the Xiaohucun site, Henan Province, China.

It is noteworthy that the $\delta^{15} \mathrm{~N}$ values of some burials did not correlate with the corresponding tomb size although a general relationship between the two variables was observed as mentioned above. The reasons for this are complex and unknown but could be related to the slow turnover rate of bone collagen which averages the general dietary protein isotope signatures of the last decades of life $[25,26]$. If an individual fell on financial or social misfortune and their social standing was diminished during the later years of their life, this could account for a difference in the social status of their burial vs. Their lifetime diet. For example, the $\delta^{15} \mathrm{~N}$ result $(10.8 \%$ o) of M90 was high and he was buried with some bronze funerary objects suggesting a possible elevated social standing during life, but the small size of his tomb $\left(3.95 \mathrm{~m}^{2}\right)$, shallow burial depth $(0.66 \mathrm{~m})$, and the fact that he was only buried in a single coffin could imply that his social status or personal fortunes declined later in life. In addition, the reverse scenario could be envisioned for the M30 burial. This individual had a $\delta^{13} \mathrm{C}$ value $\left(-15.2 \%\right.$ o) which was radically different that the rest of the population and the lowest $\delta^{15} \mathrm{~N}$ value $(7.6 \%$ o) of all the perceived elite burials. This is possible evidence that this person was a commoner that immigrated to the Xiaohucun community, and that this individual was not born into elite status but acquired it later in life, possibly though marriage, accumulation of wealth, or behavior (bravery in battle). However, all of these possibilities are speculative scenarios and addition research is necessary (ancient DNA, sulfur and strontium stable isotope ratios, etc.) to better understand these patterns, and variables such as age and sex should also be considered in future studies that examine Shang Dynasty sites for social stratification with stable isotope ratio analysis.

\section{Conclusions}

Here, we applied isotopic measurements as a direct technique to determine dietary patterns related to social class at the site of Xiaohucun, Henan Province, China. For the most part, the population was found to be consuming a predominately $\mathrm{C}_{4} \operatorname{diet}$ (millets), although a single individual (M30) was found 
to have a mixed $C_{4} / C_{3}$ diet and could have been an immigrant to the community. No difference was found in the $\delta^{13} \mathrm{C}$ results of the individuals buried with bronze vessels $(-9.1 \pm 2.8 \%$ o $)$ and the individuals buried without bronze vessels $\left(-8.2 \pm 0.7 \%\right.$ o) but significant differences were present in the $\delta^{15} \mathrm{~N}$ values: individuals buried with bronze vessels $(10.3 \pm 1.6 \%$ o) vs. individuals buried without bronze vessels $(8.0 \pm 0.9 \%$ o). Isotopic results were then compared by the number of burial coffins that an individual had: double, single, or without coffin. No difference was found in the $\delta^{13} \mathrm{C}$ values, but variations were observed in the $\delta^{15} \mathrm{~N}$ values: double $(10.2 \pm 1.7 \%$ o $)>$ single $(8.8 \pm 1.8 \%$ o $)>$ no coffin $(8.0 \pm 1.3 \%$ o $)$, possible evidence of increased animal protein consumption with higher social status. Lastly, isotopic results and status were examined by the number of coffins and tomb size. Again, no correlation was seen with $\delta^{13} \mathrm{C}$, but a linear correlation $\left(R^{2}=0.85\right)$ was found for the $\delta^{15} \mathrm{~N}$ values of the elites. Thus, additional social stratification could have existed among the elites with owners' wealthy/power enough to build larger tombs and possibly consuming more animal protein in their diets. These preliminary results of this pilot study offer a glimpse of the social hierarchy that existed during the late Shang Dynasty.

Author Contributions: Conceptualization, N.W.; resource, L.J.; Formal analysis, Y.S.; writing-original draft preparation, N.W.; writing-review and editing, N.W., X.J. All authors have read and agreed to the published version of the manuscript.

Funding: This research was funded by the National Natural Science Foundation of China, grant number 41603009, 41771223, The Ministry of education of Humanities and Social Science project, grant number 16YJCZH100 and National Social Science Foundation of China, grant number 18CKG023.

Acknowledgments: The authors thank Hu Yaowu (Fudan University, Shanghai) and Li Xiaoqiang (Institute of Vertebrate Paleontology and Paleoanthropology, CAS, Beijing) for supporting this study. Thanks to Guo Yi (Zhejiang University, Hangzhou) and Chen Xianglong (Institute of Archaeology, CASS, Beijing) for helpful comments. Wang Tingting and Zhang Xinyu (Institute of Vertebrate Paleontology and Paleoanthropology, CAS, Beijing) are thanked for collagen preparation.

Conflicts of Interest: The authors declare no conflict of interest.

\section{References}

1. Liu, L. The Chinese Neolithic: Trajectories to Early States (New Studies in Archaeology); Cambridge University Press: Cambridge, UK, 2007.

2. Liu, L.; Chen, X.C. The Archaeology of China: From the Late Paleolithic to the Early Bronze Age; Cambridge University Press: Cambridge, UK, 2012.

3. IA CASS. Chinese Archaeology: The Volume of Shang and Xia Dynasties; China Social Sciences Press: Beijing, China, 2003; pp. 98-101. (In Chinese)

4. IA CASS. Chinese Archaeology: The Volume of Neolithic; China Social Sciences Press: Beijing, China, 2010; pp. 788-801. (In Chinese)

5. Dai, S. Li Ji: Book of Rites; The North Literature and Art Publishing Houses: Harbin, China, 2013 ; p. 437. (In Chinese)

6. Xun, K. Xunzi; Yan Shi Press: Beijing, China, 2011; p. 658. (In Chinese)

7. Wang, W. The social structure of Zhou dynasty reflects by tomb system and comparisons with Shang dynasty. Sci. Chi. 2004, 3, 54-55. (In Chinese)

8. Binford, L.R. Mortuary Practices: Their Study and Potential. Mem. Soc. Am. Archaeol. 1971, 25, 6-29. [CrossRef]

9. Binford, L.R. Meaning, Inference, and the Material Record. In Ranking, Resource, and Exchange; Cambridge University Press: Cambridge, UK, 1982; pp. 160-163.

10. O'Shea, J.M. Social Configurations and the Archaeological Study of Mortuary Practices: A Case Study. In The archaeology of Death; Chapman, R., Kinnes, I., Randsborg, K., Eds.; Cambridge University Press: Cambridge, UK, 1981; pp. 39-52.

11. O'Shea, J.M. Mortuary Custom in Bronze Age of Southeastern Hungary, Diachronic and Synchronic Perspectives. In Regional Approaches to Mortuary Analysis: Interdisciplinary Contributions to Archaeology; Lane, A.B., Ed.; Springer: Berlin, Germany, 1995; pp. 125-145.

12. Saxe, A.A. Social Dimensions of Mortuary Practices in a Mesolithic Population from Wadi Halfa, Sudan. Ph.D. Thesis, Department of Anthropology, University of Michigan, Ann Arbor, MA, USA, 1970. 
13. Van der Merwe, N.J.; Vogel, J.C. ${ }^{13} \mathrm{C}$ content of human collagen as a measure of prehistoric diet in woodland North America. Nature 1978, 276, 815-816. [CrossRef] [PubMed]

14. Schoeninger, M.J.; DeNiro, M.J. Nitrogen and carbon isotopic composition of bone collagen from marine and terrestrial animals. Geochim. Cosmochim. Acta. 1984, 48, 625-639. [CrossRef]

15. Sealy, J.C.; van der Merwe, N.J.; Thorp, J.A.L.; Lanham, J.L. Nitrogen isotopic ecology in southern Africa: Implications for environmental and dietary tracing. Geochim. Cosmochim. Acta. 1987, 51, 2707-2717. [CrossRef]

16. Katzenberg, M.A.; Weber, A. Stable isotope ecology and palaeodiet in the Lake Baikal region of Siberia. J. Archaeol. Sci. 1999, 26, 651-659. [CrossRef]

17. Valentin, F.; Bocherens, H.; Gratuze, B.; Sand, C. Dietary patterns during the late prehistoric/historic period in Cikobia Island (Fiji): Insights from stable isotopes and dental pathologies. J. Archaeol. Sci. 2006, 33, 1396-1410. [CrossRef]

18. Müldner, G.; Richards, M.P. Stable isotope evidence for 1500 years of human diet at the city of York, UK. Am. J. Phys. Anthropol. 2007, 133, 682-697. [CrossRef]

19. Choy, K.; Jean, O.R.; Fuller, B.T.; Richards, M.P. Isotopic evidence of dietary variations and weaning practices in the Gaya cemetery at Yeanri, Gimhae, South Korea. Am. J. Phys. Anthropol. 2010, 142, 74-84. [CrossRef]

20. Bourbou, C.; Fuller, B.T.; Garvie-Lok, S.J.; Richards, M.P. Reconstructing the diets of Greek Byzantine populations (6th-15th centuries AD) using carbon and nitrogen stable isotope ratios. Am. J. Phys. Anthropol. 2011, 146, 569-581. [CrossRef]

21. Commendador, A.S.; Dudgeon, J.V.; Finney, B.P.; Fuller, B.T.; Esh, K.S. Stable isotope $\left(\delta^{13} \mathrm{C}\right.$ and $\left.\delta^{15} \mathrm{~N}\right)$ perspective on human diet on Rapa Nui (Easter Island) c.a. 1400-1900 AD. Am. J. Phys. Anthropol. 2013, 152, 173-185. [PubMed]

22. Cui, Y.; Song, L.; Wei, D.; Pang, Y.; Wang, N.; Ning, C.; Li, C.; Feng, B.; Tang, W.; Li, H.; et al. Identification of kinship and occupant status in Mongolian noble burials of the Yuan Dynasty through a multidisciplinary approach. Philos. Trans. R. Soc. Lond. B. Biol. Sci. 2015, 370, 20130378. [CrossRef] [PubMed]

23. Ma, M.M.; Dong, G.H.; Jia, X.; Wang, H.; Cui, Y.F.; Chen, F.H. Dietary shift after 3600 cal yr BP and its influencing factors in northwestern China: Evidence from stable isotopes. Quat. Sci. Rev. 2016, 145, 57-70. [CrossRef]

24. Chen, X.L.; Fang, Y.M.; Hu, Y.W.; Hou, Y.F.; Lu, P.; Yuan, J.; Song, G.D.; Fuller, B.T.; Richards, M.P. Isotopic Reconstruction of the Late Longshan Period (ca.4200-3900BP) Dietary Complexity before the Onset of State-Level Societies at the Wadian Site. Int. J. Osteoarchaeol. 2016, 26, 808-817. [CrossRef]

25. Stenhouse, M.J.; Baxter, M.S. The uptake of bomb ${ }^{14} \mathrm{C}$ in humans, in radiocarbon dating. In Radiocarbon Dating: Proceedings of the Ninth International Conference, Los Angeles and La Jolla; Berger, R., Suess, H.E., Eds.; University of California Press: Berkeley, CA, USA, 1979; pp. 324-341.

26. Hedges, R.E.M.; Clement, J.G.; Thomas, C.D.L.; O'Connell, T.C. Collagen turnover in the adult femoral mid-shaft: Modeled from anthropogenic radiocarbon tracer measurements. Am. J. Phys. Anthropol. 2007, 133, 808-816. [CrossRef]

27. Schwarcz, H.P.; Schoeninger, M.J. Stable isotopic analyses in human nutritional ecology. Yearb. Phys. Anthropol. 1991, 34, 283-321. [CrossRef]

28. Pechenkina, E.A.; Ambrose, S.H.; Ma, X.; Benfer, J.R.A. Reconstructing northern Chinese Neolithic subsistence practices by isotopic analysis. J. Archaeol. Sci. 2005, 32, 1176-1189. [CrossRef]

29. Hu, Y.; Wang, S.; Luan, F.; Wang, C.; Richards, M.P. Stable isotope analysis of humans from Xiaojingshan site: Implications for understanding the origin of millet agriculture in China. J. Archaeol. Sci. 2008, 35, 2960-2965. [CrossRef]

30. Barton, L.; Newsome, S.D.; Chen, F.H.; Wang, H.; Guilderson, T.P.; Bettinger, R.L. Agricultural origins and the isotopic identity of domestication in northern China. Proc. Natl. Acad. Sci. USA 2009, 106, 5523-5528. [CrossRef]

31. Fu, Q.M.; Jin, S.A.; Hu, Y.W.; Ma, Z.; Pan, J.C.; Wang, C.S. Agricultural development and human diets in Gouwan site, Xichuan, Henan. Chin. Sci. Bull. 2010, 55, 614-620. [CrossRef]

32. Atahan, P.; Dodson, J.; Li, X.; Zhou, X.; Hu, S.; Bertuch, F.; Sun, N. Subsistence and the isotopic signature of herding in the Bronze Age Hexi Corridor, NW Gansu, China. J. Archaeol. Sci. 2011, 38, 1747-1753. [CrossRef]

33. Lanehart, R.E.; Tykot, R.H.; Underhill, A.P.; Luan, F.; Yu, H.; Fang, H.; Feinman, G.; Nicholas, L. Dietary adaptation during the Longshan period in China: Stable isotope analyses at Liangchengzhen (southeastern Shandong). J. Archaeol. Sci. 2011, 38, 2171-2181. [CrossRef] 
34. Liu, X.; Jones, M.K.; Zhao, Z.; Liu, G.; O'Connell, T.C. The earliest evidence of millet as a staple crop: New light on neolithic foodways in North China. Am. J. Phys. Anthropol. 2012, 149, 283-290. [CrossRef] [PubMed]

35. Atahan, P.; Dodson, J.; Li, X.; Zhou, X.; Chen, L.; Barry, L.; Bertuch, F. Temporal trends in millet consumption in northern China. J. Archaeol. Sci. 2014, 50, 171-177. [CrossRef]

36. Hu, Y.W.; Luan, F.S.; Wang, C.S.; Richards, M.P. Preliminary attempt to distinguish the domesticated pigs from wild boars by the methods of carbon and nitrogen stable isotope analysis. Sci. China. Earth. Sci. 2009, 52, 85-92. [CrossRef]

37. Chen, X.L.; Yuan, J.; Hu, Y.W.; He, N.; Wang, C.S. Animal feeding practice at Taosi site. Archaeology 2012, 9 , 75-82. (In Chinese)

38. Chen, X.L.; Hu, S.M.; Hu, Y.W.; Ma, R.Y.; Wang, W.L.; Lu, P.; Wang, C.S. Raising practices of Neolithic livestock evidenced by stable isotope analysis in the Wei River valley, North China. Int. J. Osteoarchaeol. 2014, 26, 42-52. [CrossRef]

39. Hou, L.L.; Hu, Y.W.; Zhao, X.P.; Li, S.T.; Wei, D.; Hou, Y.F.; Hu, B.H.; Lv, P.; Li, T.; Song, G.D.; et al. Human subsistence strategy at Liuzhuang site, Henan, China during the proto-Shang culture ( 2000-1600 BC) by stable isotopic analysis. J. Archaeol. Sci. 2013, 40, 2344-2351. [CrossRef]

40. Bocherens, H.; Drucker, D. Trophic level isotopic enrichment of carbon and nitrogen in bone collagen: Case studies from recent and ancient terrestrial ecosystems. Int. J. Osteoarchaeol. 2003, 13, 46-53. [CrossRef]

41. Reitsema, L.J. Beyond diet reconstruction: Stable isotope applications to human physiology, health, and nutrition. Am. J. Hum. Biol. 2013, 25, 445-456. [CrossRef]

42. Bol, R.; Pflieger, C. Stable isotope $\left({ }^{13} \mathrm{C},{ }^{15} \mathrm{~N}\right.$ and $\left.{ }^{34} \mathrm{~S}\right)$ analysis of the hair of modern humans and their domestic animals. Rapid. Commun. Mass. Spectrom. 2002, 16, 2195-2200. [CrossRef]

43. Petzke, K.J.; Boeing, H.; Metges, C.C. Choice of dietary protein of vegetarians and omnivores is reflected in their hair protein C-13 and N-15 abundance. Rapid. Commun. Mass. Spectrom. 2005, 19, 1392-1400. [CrossRef]

44. Katzenberg, M.A. Stable isotope analysis: A tool for studying past diet, demography, and life history. In Biological Anthropology of the Human Skeleton; Katzenberg, M.A., Saunders, S.R., Eds.; Wiley-Liss: New York, NY, USA, 2000; pp. 305-327.

45. Ambrose, S.H.; Krigbaum, J. Bone chemistry and bioarchaeology. J. Anthropol. Archaeol. 2003, 22, $193-199$. [CrossRef]

46. Lee-Thorp, J.A. On isotopes and old bones. Archaeometry 2008, 50, 925-950. [CrossRef]

47. Richards, M.P.; Hedges, R.E.M.; Molleson, T.I.; Vogel, J.C. Stable isotope analysis reveals variations in human diet at the Poundbury Camp cemetery site. J. Archaeol. Sci. 1998, 25, 1247-1252. [CrossRef]

48. Ambrose, S.H.; Buikstra, J.; Krueger, H.W. Status and gender differences in diet at Mound 72, Cahokia, revealed by isotopic analysis of bone. J. Anthropol. Archaeol. 2003, 22, 217-226. [CrossRef]

49. Kjellström, A.; Jan Storå, J.; Göran Possnert, G.; Linderholm, A. Dietary patterns and social structures in Medieval Sigtuna, Sweden, as reflected in stable isotope values in human skeletal remains. J. Archaeol. Sci. 2009, 36, 2689-2699. [CrossRef]

50. Yoder, C. Let them eat cake? Status-based differences in diet in medieval Denmark. J. Archaeol. Sci. 2012, 39, 1183-1193. [CrossRef]

51. Quintelier, K.; Ervynck, A.; Müldner, G.; Van Neer, W.; Richards, M.P.; Fuller, B.T. Isotopic Examination of Links Between Diet, Social Differentiation, and DISH at the Post-Medieval Carmelite Friary of Aalst, Belgium. Am. J. Phys. Anthropol. 2014, 153, 203-213. [CrossRef]

52. Dong, Y.; Morgan, C.; Chinenov, Y.; Zhou, L.G.; Fang, W.Q.; Ma, X.L.; Pechenkina, K. Shifting diets and the rise of male-biased inequality on the Central Plains of China during Eastern Zhou. Proc. Natl. Acad. Sci. USA 2017, 114, 932-937. [CrossRef]

53. Twiss, K. The archaeology of food and social diversity. J. Archaeol. Res. 2012, 20, 357-395. [CrossRef]

54. Henan Provincial Institute of Cultural Relics and Archaeology. Xipo Cemetery, Lingbao; Cultural Relics Press: Beijing, China, 2010. (In Chinese)

55. Ling, X.; Chen, L.; Tian, Y.Q.; Li, Y.; Zhao, C.C.; Hu, Y.W. Carbon and Nitrogen Stable Isotopic Analysis on Human Bones from the Qin Tomb of Sun jianantou Site, Fengxiang, Shaanxi Province. Acta Anthropologica Sinica 2010, 29, 54-61. (In Chinese)

56. Zhang, X.L.; Qiu, S.H.; Zhong, J.; Liang, Z.H. The carbon, nitrogen stable isotope analysis of human bone from Qianzhangda Cemetery. Archaeology 2012, 9, 83-90. (In Chinese) 
57. Zhang, X.L.; Qiu, S.H.; Zhang, J.; Guo, W. The carbon and nitrogen stable isotope analysis of human bones from Duogang cemetery, Xinjiang. South. Antiq. 2014, 3, 79-91. (In Chinese)

58. Wang, Y.; Nan, P.H.; Wang, X.Y.; Wei, D.; Hu, Y.W.; Wang, C.S. Dietary Differences in Humans with Similar Social Hierarchies: Example from the Niedian Site, Shanxi. Acta Anthropologica. Sinica 2014, 33, 82-89. (In Chinese)

59. Li, C. Anyang; University of Washington Press: Seattle, WA, USA, 1978.

60. Chang, K.C. Shang Civilization; Yale University Press: New Haven, CT, USA, 1980.

61. Loewe, M.; Shaughnessy, E.L. The Cambridge History of Ancient China: From the Origins of Civilization to 221 B.C.; Cambridge University Press: Cambridge, UK, 1999.

62. Thorp, R.L. China in the Early Bronze Age: Shang Civilization; University of Pennsylvania Press: Philadelphia, PA, USA, 2005; p. 320.

63. Zhu, Y. The Origin, Migration and Development of Shang Clan; The Commercial Press: Beijing, China, 2007. (In Chinese)

64. Zhang, G.Z. Shang Civilization; SDX Joint Publishing Company: Beijing, China, 2013. (In Chinese)

65. Henan Provincial Institute of Cultural Relics and Archaeology. Unearthing bulletin for late Shang remains of Guandimiao ruins in Xingyang City of Henan Province. Archaeology 2008, 7, 32-46. (In Chinese)

66. Song, Z.H. The Social Life History of Xia and Shang Dynasty; China Social Sciences Press: Beijing, China, 1994. (In Chinese)

67. Song, Z.H. China Diet History: Xia and Shang Dynasty; Huaxia Press: Beijing, China, 1999. (In Chinese)

68. Song, Z.H. Social Lives and Rituals in Shang Dynasty; China Social Sciences Press: Beijing, China, 2010. (In Chinese)

69. Wang, X. Dietetic rules and regulations research in Zhouli. Master's Thesis, Yangzhou University, Yangzhou, China, 2007. (In Chinese).

70. Wang, Y.X.; Xu, Y.H. Countries and Society in Shang Dynasty; China Social Sciences Press: Beijing, China, 2011. (In Chinese)

71. Tang, J.G. The Social Organization of Late Shang China: A Mortuary Perspective. Ph.D. Thesis, University of London, London, UK, 2004.

72. Yu, W.C.; Gao, M. The study of the system with the tripod at Zhou dynasty. J. Peking Univ. Philosophy Soc. Sci. 1978, 2, 84-97. (In Chinese)

73. Reinhart, K. Ritual feasting and empowerment at Yanshi Shangcheng. J. Anthropol. Archaeol. 2015, 39, 76-109. [CrossRef]

74. Qing, L. Type value and grave value: An introduction to a quantifying method in tomb research. Huaxia Archaeol. 2007, 3, 133-137. (In Chinese)

75. Wu, F. The research of funeral furniture of Shang Dynasty. Master's Thesis, Zhengzhou University, Zhengzhou, China, 2012. (In Chinese).

76. Jia, L.M.; Zeng, X.; Liang, F.; Yu, H.W. The Xiaohucun late Shang noble cemetery of Xiangyang city, Hennan. In Archaeological Society of China, Important Archaeology Discoveries in China of 2006; Cultural Relics Press: Beijing, China, 2007. (In Chinese)

77. Lee, G.; Crawford, G.W.; Liu, L.; Chen, X. Plants and people from the early Neolithic to Shang periods in North China. Proc. Natl. Acad. Sci. USA 2007, 104, 1087-1092. [CrossRef]

78. Qiu, S.H.; Zhong, J.; Zhao, X.P.; Sun, F.X.; Cheng, L.Q.; Guo, Y.Q.; Li, X.W.; Ma, X.L. Studies on Diet of the Ancient People of the Yangshao Cultural Sites in the Central Plains. Acta Anthropol. Sin. 2010, 29, 197-207. (In Chinese)

79. IA CASS. Science for Archaeology: The Third Volume; Science Press: Beijing, China, 2011; pp. 1-35. (In Chinese)

80. Liu, X.; Lightfoot, E.; O'Connell, T.C.; Wang, H.; Li, S.; Zhou, L.; Hu, Y.; Motuzaite-Matuzeviciute, G.; Jones, M.K. From necessity to choice: Dietary revolutions in west China in the second millennium BC. World Archaeol. 2014, 46, 661-680. [CrossRef]

81. Jia, L.M.; Wang, W.B.; Lu, H.W.; Liang, F.W.; Zeng, X.M. Archaeological Excavation of Xiaohucun village cemetery in Xingyang, Henan Province. Huaxia Archaeol. 2015, 1, 3-25. (In Chinese)

82. Zhu, H. Physical Anthropology; Higher Education Press: Beijing, China, 2004. (In Chinese)

83. Richards, M.P.; Hedges, R.E.M. Stable isotope evidence for similarities in the types of marine foods used by Late Mesolithic humans at sites along the Atlantic coast of Europe. J. Archaeol. Sci. 1999, 26, 717-722. [CrossRef] 
84. DeNiro, M.J. Postmortem preservation and alteration of in vivo bone collagen isotope ratios in relation to palaeodietary reconstruction. Nature 1985, 317, 806-809. [CrossRef]

85. Zhang, X.L.; Wang, J.X.; Xian, Z.Q.; Qiu, S.H. Studies on ancient human diet. Archaeology 2003, 2, 62-75. (In Chinese)

86. Dai, L.; Li, Z.; Zhao, C.; Yuan, J.; Hou, L.; Wang, C.; Fuller, B.T.; Hu, Y. An isotopic perspective on animal husbandry at the Xinzhai site during the initial stages of the legendary Xia Dynasty (2070-1600 BC). Int. J. Osteoarchaeol. 2015. [CrossRef]

87. IA CASS. Science for Archaeology: The Second Volume; Science Press: Beijing, China, 2007; pp. 1-34. (In Chinese)

88. Xu, Z.Y.; Chang, P.Y. Zhou Li: Translation and Annotation; Zhonghua Book Company: Shanghai, China, 2014. (In Chinese)

89. Liu, S.C. Chunqiu Gongyang Zhuan: Translation and Annotation; Zhonghua Book Company: Shanghai, China, 2011. (In Chinese)

(C) 2020 by the authors. Licensee MDPI, Basel, Switzerland. This article is an open access article distributed under the terms and conditions of the Creative Commons Attribution (CC BY) license (http://creativecommons.org/licenses/by/4.0/). 